\title{
Ethanol Tolerance and the Induction of Stress Proteins by Ethanol in Candida albicans
}

\author{
By MARIE L. ZEUTHEN, NINA DABROWA, CHIAKA M. ANIEBO† AND \\ D. H. HOW ARD* \\ Department of Microbiology and Immunology, UCLA School of Medicine, Los Angeles, \\ California 90024, USA
}

(Received 4 January 1988)

Ethanol is one of the products of the metabolism of glucose by Candida albicans. The amount produced is directly related to the concentration of glucose in the medium. The fungus utilizes ethanol as a sole source of carbon but is relatively intolerant of ethanol in its environment. Ethanol induces germ tube formation by blastoconidia of $C$. albicans. Germination was not seen under fermentation conditions even though the amount of ethanol produced was in the range that induced germ tubes when added to phosphate buffer. Ethanol also induces $C$. albicans to form stress proteins that are similar to heat shock proteins. The possibility that stress proteins may regulate germ tube formation by $C$. albicans is discussed.

\section{INTRODUCTION}

The commensal fungus Candida albicans produces ethanol from the fermentation of glucose (Pappagianis \& Marovitz, 1966; Wilson et al., 1966). This aspect of the biology of the fungus has not received much attention beyond the curious reports of persons suffering symptoms of drunkenness due to the in vivo fermentation of certain foods by Candida spp. (Iwata, 1976).

During studies on the characteristics of a nongerminating variant of $C$. albicans (Howard et al., 1986) we noted that the growth of $C$. albicans was retarded by low levels $(1 \%, \mathrm{v} / \mathrm{v})$ of ethanol that were used to dissolve certain inhibitors of respiration. Such intolerance was greater than that reported for Saccharomyces cerevisiae (Casey \& Ingledew, 1986) and apparently ethanol sensitivity has not been studied previously in C. albicans (Odds, 1979; Shepherd et al., 1985).

Ethanol promotes germ tube formation in C. albicans (Pollack \& Hashimoto, 1985) and it would be interesting to know if the amount of metabolically generated ethanol is in the range to induce blastoconidial germination. Ethanol tolerance in C. albicans is also of interest in relation to the stress response because it has been reported that ethanol induces heat shock proteins and thermotolerance in $S$. cerevisiae (Plesset et al., 1982). We have reported on the heat shock proteins (HSPs) observed in C. albicans in response to temperature shifts (Dabrowa \& Howard, 1984). Recently, we described a number of HSPs that appear to be involved in the thermotolerance of the fungus (Zeuthen \& Howard, 1986). We have also discovered that some of the stress proteins formed in response to ethanol are similar to the HSPs (Dabrowa et al., 1986). The notion that stress proteins may be involved in the regulation of germ tube formation by $C$. albicans is developed in the Discussion section of this paper. Thus at the outset of our studies we thought that ethanol production and tolerance might be of concern in studies on morphogenesis in C. albicans.

\footnotetext{
$\dagger$ Permanent address: Department of Microbiology, Faculty of Sciences, University of Port Harcourt, Port Harcourt, Rivers State, Nigeria, West Africa.

Abbreviations: ESP, ethanol stress proteins; GPA, glucose/peptone agar; GPB, glucose/peptone broth; HSP, heat shock proteins; LBC, synthetic medium of Lee et al. (1975); NSP, nutritional stress proteins; YNB, yeast nitrogen base without amino acids.
} 
In this report we present the results of observations on: (i) the ethanol tolerance of C.albicans; (ii) the growth of $C$. albicans on ethanol as a sole source of carbon; (iii) the production of ethanol from glucose by the fungus; (iv) the formation of germ tubes by $C$. albicans in the presence of ethanol; and (v) the stress-response proteins (ESPs) formed by C. albicans in the presence of ethanol.

\section{METHODS}

Organisms. Candida albicans strains were 300 (3153A, Dabrowa \& Howard, 1984), 304 (ATCC 28121), 320 (FC18, Gibbons \& Howard, 1986; ATCC 62376) and 336, a recent isolate identified in our laboratory by standard methods (McGinnis, 1980). Stock cultures are preserved in the Fungus Collection, University of California, Los Angeles, Calif., USA. Working cultures were maintained on GPA (see below) in a refrigerator and subcultured every month.

Media. Glucose/peptone agar (GPA) contained 2\% (w/v) Bacto Dextrose (Difco), $1 \%$ (w/v) Bacto Peptone (Difco) and $2 \%$ (w/v) Bacto Agar (Difco). Glucose/peptone broth (GPB) had the same constituents without the agar. Yeast Nitrogen Base without amino acids (YNB) was prepared in accordance with the manufacturer's instructions (Difco). LBC synthetic medium was constructed as described by Lee et al. (1975). Chemicals, including amino acids, were purchased from Sigma, Calbiochem or Eastman Kodak.

Ethanol tolerance. Cells of strain 300 were grown in $50 \mathrm{ml}$ YNB with $1 \%$ glucose contained in $300 \mathrm{ml}$ nepheloflasks with side arms (Bellco Glass). Ethanol at concentrations of 1,2 and $5 \%(\mathrm{v} / \mathrm{v})$ was added to the flasks at the time of inoculation. The flasks were designed to prevent loss of ethanol by evaporation. Cells for study were grown on GPA at $37^{\circ} \mathrm{C}$ for $24 \mathrm{~h}$, harvested, and washed twice in sterile distilled water. Growth was initiated at a cell concentration of about $5 \times 10^{6}$ cells $\mathrm{ml}^{-1}$. The cultures were grown on a rotary shaker (New Brunswick) at $37^{\circ} \mathrm{C}$ and growth was assessed at regular intervals by measuring density with a Klett-Summerson photoelectric colorimeter (red filter).

Further studies of ethanol tolerance were done by measuring the effect of ethanol on yeast cell viability. Different concentrations of ethanol (5-13\%) were added to nepheloflasks containing $50 \mathrm{ml}$ YNB with $1 \%$ glucose. Cells of strain 300 were grown, harvested and washed as described above, and were inoculated into the flasks to give a final concentration of about $5 \times 10^{6}$ cells ml-1. The inoculated flasks were incubated at $37^{\circ} \mathrm{C}$ on a gyrotary shaker for $24 \mathrm{~h}$. Samples $(1 \mathrm{ml})$ were withdrawn at regular intervals, diluted in distilled water and plated in duplicate on GPA. The plates were incubated at $25^{\circ} \mathrm{C}$ for $5-7 \mathrm{~d}$ after which the no. of colonies (c.f.u.) was recorded.

Germ tube formation. Cells of strains $300,304,320$ and 336 were grown at $25^{\circ} \mathrm{C}$ on GPA for $24 \mathrm{~h}$. The cells were harvested, washed once in distilled water and resuspended in $0.033 \mathrm{M}$-potassium phosphate buffer (pH 7.0) to a concentration of $1 \times 10^{7}$ cells $\mathrm{ml}^{-1}$. Different amounts of ethanol were added to $1 \mathrm{ml}$ phosphate buffer. The cells were added to ethanol/buffer mixtures at a concentration of about $1 \times 10^{6} \mathrm{cells} \mathrm{ml}^{-1}$ and the inoculated tubes were incubated at $37^{\circ} \mathrm{C}$ for $3 \mathrm{~h}$. Cells prepared in the same manner were inoculated into LBC medium to measure the germ tube forming ability of the cells in each inoculum. The controls were incubated in the same manner. At the end of the incubation period the tubes were agitated gently on a Multipurpose Rotator, model 150 (Scientific Industries). A loopful of cells from each tube was examined microscopically. The percentage of cells with germ tubes was determined by counting 100 cells. Each count was repeated three times and the mean of the three counts recorded.

Growth of C. albicans in ethanol as a sole source of carbon. Cells of strain 300 and 336 were grown for $24 \mathrm{~h}$ at $37^{\circ} \mathrm{C}$ on YNB with $1 \%$ glucose. The cells were harvested, washed with distilled water and resuspended in distilled water at a concentration of about $1 \times 10^{7}$ cells $\mathrm{ml}^{-1}$. Ethanol was added to YNB contained in nepheloflasks with airtight caps. The following concentrations of ethanol or glucose were studied: no carbon source; $0.25 \%$ ethanol; $0.50 \%$ ethanol $; 1.0 \%$ ethanol; and $1.0 \%$ glucose. The flasks were inoculated with about $5 \times 10^{6} \mathrm{cells}^{-1}$. The cultures were grown on a rotary shaker at $37^{\circ} \mathrm{C}$ and growth was assessed at regular intervals by measuring density with a Klett-Summerson photoelectric colorimeter.

Ethanol production by C. albicans. Cells of strain 300 or 336 were grown in YNB with $1 \%$ glucose at $37^{\circ} \mathrm{C}$. Cells were harvested and washed as indicated above and inoculated into flasks of YNB which were supplemented with $1,2,5,7,10$ or $15 \%$ glucose. The flasks were incubated at $37{ }^{\circ} \mathrm{C}$ on a rotary shaker. At different time intervals samples were removed and the level of ethanol determined by means of Sigma kit no. 331. The amount of residual glucose was determined enzymically (glucose oxidase) on the Beckman ASTRA.

Radiolabelling techniques and gel electrophoresis. Cells of strain 300 grown on GPA slants were harvested after $24 \mathrm{~h}$ at 23 or $37^{\circ} \mathrm{C}$ and were used to inoculate YNB agar plates. After $24 \mathrm{~h}$ at $23^{\circ} \mathrm{C}$, the cells were harvested, washed twice with sterile water and counted in a hemocytometer. Flasks, each containing $10 \mathrm{ml}$ YNB with $1 \%$ glucose and supplemented with $7 \%$ ethanol, were inoculated with suspensions of cells to a concentration of $2 \times 10^{7}$ cells $\mathrm{ml}^{-1}$. Flasks were incubated at $23^{\circ} \mathrm{C}$ on a rotary shaker. L- $-{ }^{35}$ S $]$ Methionine (specific activity $5 \cdot 5 \mathrm{TBq}$ $\mathrm{mmol}^{-1}$ ) to a final concentration of $0.26 \mathrm{MBq} \mathrm{ml}^{-1}$ was added to the flasks at time 0 and at $20 \mathrm{~min}$. Flasks were removed after $20 \mathrm{~min}$ labelling. Unlabelled DL-methionine (final concentration $650 \mu \mathrm{M}$ ) was added to the flasks as 
a chase and the flasks were stored on ice. Cells from all flasks were washed twice and suspended in $0 \cdot 2 \mathrm{ml} 1 \mathrm{~mm}$ phenylmethylsulphonyl fluoride in water. Glass beads $(2$ vols, $0.45 \mathrm{~mm})$ were added to each tube. Cells were broken by mixing on a vortex mixer (Vortex-Genie; Scientific Products) at maximum speed for four cycles of $30 \mathrm{~s}$ each. Cells were kept on ice during all the procedures and between vortex mixings. Microscopic examination revealed $90-95 \%$ of the cells were broken. Beads and cell wall debris were separated by centrifugation. The supernatant containing crude proteins was added to an equal volume of $0.1 \mathrm{M}$-Tris $/ \mathrm{HCl}$ (pH 6.8 ) containing $18 \%$ (v/v) glycerol, $1.8 \%(\mathrm{w} / \mathrm{v})$ SDS, $0 \cdot 18 \%(\mathrm{v} / \mathrm{v})$ 2-mercaptoethanol and $0.0018 \%(\mathrm{w} / \mathrm{v})$ bromophenol blue, and was immediately denatured at $100{ }^{\circ} \mathrm{C}$ for $2 \mathrm{~min}$. The radiolabelled proteins in the cell extracts were separated by onedimensional SDS gel electrophoresis in polyacrylamide slab gels (Dabrowa \& Howard, 1984). The amount of protein per lane was $10-15 \mu \mathrm{g}$. Proteins were separated at a constant current of $25 \mathrm{~mA}$, fixed in $50 \%(\mathrm{v} / \mathrm{v})$ methanol and $10 \%(\mathrm{v} / \mathrm{v})$ acetic acid, and stained by the silver nitrate method (Morrissey, 1981). After staining, the gel were dried onto gel bond paper and exposed to Kodak XAR-5 film at $-70^{\circ} \mathrm{C}$. Molecular mass markers were from Pharmacia. Reagents for electrophoresis were obtained from BRL and Sigma.

Cells of strain 300 used in heat shock studies were grown on GPA at $23{ }^{\circ} \mathrm{C}$ for $24 \mathrm{~h}$. The growth on the GPA plates was transferred to YNB with $1 \%$ glucose and the cells were grown to mid-exponential phase at $23^{\circ} \mathrm{C}$ on a rotary shaker. Cells were harvested, washed and inoculated at a concentration of $5 \times 10^{7} \mathrm{ml}^{-1}$ into prewarmed YNB with $1 \%$ glucose at $23{ }^{\circ} \mathrm{C}$ (control) and at $37^{\circ} \mathrm{C}$ (heat shock). Proteins were labelled with L- $\left[{ }^{35}\right.$ S $]$ methionine (specific activity $5.5 \mathrm{TBq} \mathrm{mmol}^{-1}$ ) at a final concentration of $0.26 \mathrm{MBq} \mathrm{ml}{ }^{-1}$ for 20 min pulses. Labelling was stopped with an excess of cold methionine and the preparations were immediately placed on ice, washed and held at $-20^{\circ} \mathrm{C}$. Crude proteins were obtained and gel electrophoresis was done as described above.

\section{RESULTS}

\section{Ethanol tolerance in C. albicans}

It had been noted in a previous study that the growth of a nongerminating variant of $C$. albicans (strain 300-SG) and its parent (strain 300$)$ was depressed by $1.0 \%(\mathrm{v} / \mathrm{v} ; 171 \mathrm{~mm}$ ) ethanol used as a diluent for two inhibitors of respiration (Howard et al., 1986). This effect was studied in more detail. Cells of strain 300 were inoculated into flasks of YNB with $0,1,2$ and $5 \%$ ethanol. The characteristics of growth of strain 300 in YNB with $1 \%$ glucose were the same as those previously recorded (Howard et al., 1986). Both 1 and $2 \%$ ethanol retarded growth and $5 \%$ ethanol completely suppressed it for $24 \mathrm{~h}$ at $37^{\circ} \mathrm{C}$ (Fig. 1). The ethanol tolerance of C. albicans strain 300 was relatively low in comparison to some other species of yeasts (Casey \& Ingledew, 1986).

Similar experiments were done with strains 300,304 and 336 (Table 1). The measure of inhibition was the length of the lag period of growth and the generation time during exponential growth. Strains 300 and 304 behaved similarly, while strain 336 seemed to be even more sensitive to ethanol. Therefore, three strains of $C$. albicans of different origin all showed relative intolerance to ethanol.

We also tested the effect of ethanol on yeast cell viability (Fig. 2). A $90 \%$ reduction in the no. of c.f.u. $\mathrm{ml}^{-1}$ occurred after $10 \mathrm{~h}$ at $5 \%$ ethanol, by $7 \mathrm{~h}$ at $7 \%$ ethanol, by $6 \mathrm{~h}$ at $9 \%$ ethanol, by $3 \mathrm{~h}$ at $11 \%$ ethanol, and in as little as $1 \mathrm{~h}$ at $13 \%$ ethanol.

\section{Ethanol as a sole carbon source}

Results recorded in the early literature are contradictory about ethanol utilization by $C$. albicans. We decided to see if the strains used in our study utilized ethanol. Strains 300 and 336 were grown in YNB with $1 \%$ glucose or with various concentrations of ethanol $(0.25,0.5$ and $1 \%$ ). Utilization of ethanol as a sole source of carbon was clearly displayed by both strains (Fig. 3). The low tolerance of $C$. albicans towards ethanol was again observed in that the growth of the fungus was retarded in $1 \%$ ethanol (Fig. 3).

\section{Production of ethanol from glucose}

Flasks of YNB supplemented with different concentrations of glucose were inoculated with cells of strain 300 ; samples taken at regular intervals were tested for ethanol production and glucose depletion (Table 2). In $1 \%$ glucose strain 300 produced $0.33 \%(w / v)$ ethanol after $17 \mathrm{~h}$ incubation, when all glucose had been utilized. After a lag period of about $4 \mathrm{~d}$ the ethanol began to disappear as a result of utilization by the fungus. In $2 \%$ glucose the fungus produced about 


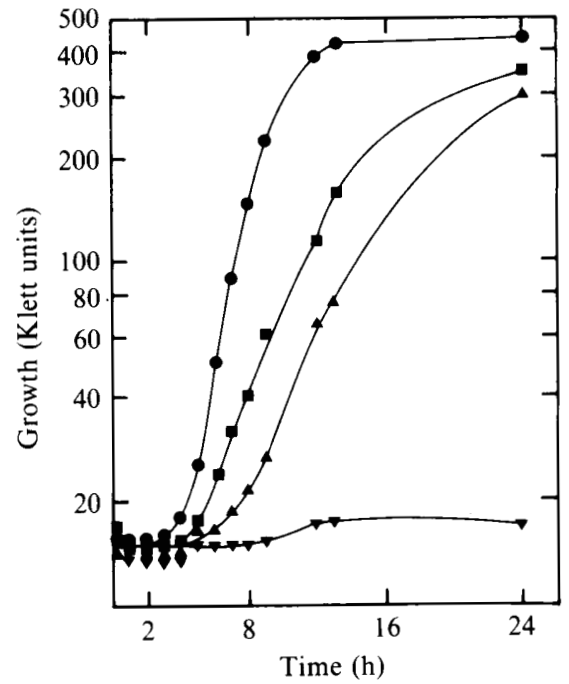

Fig. 1

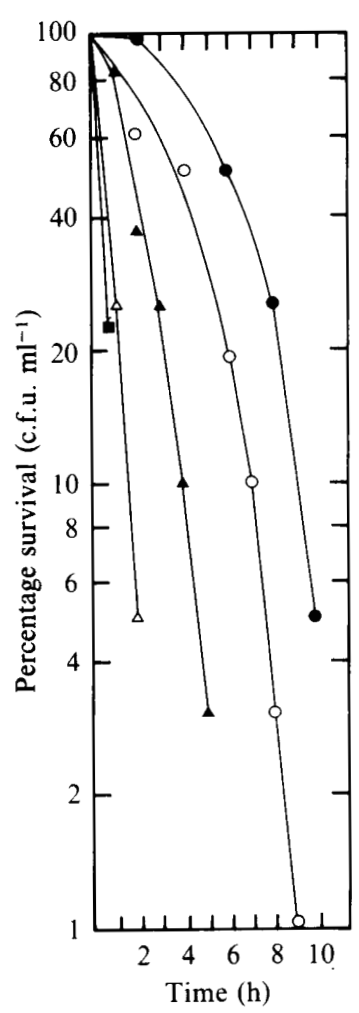

Fig. 2

Fig. 1. Effect of ethanol on the growth of C. albicans. About $5 \times 10^{6}$ cells $\mathrm{ml}^{-1}$ were inoculated into YNB with $1 \%(\mathrm{w} / \mathrm{v})$ glucose supplemented with different concentrations of ethanol. Growth was measured in a Klett-Summerson photoelectric colorimeter. Ethanol concentrations $(v / v)$ were $1 \%(\square)$, $2 \%(\Delta)$ or $5 \%(\nabla)$, Control (no ethanol).

Fig. 2. Effect of ethanol on the viability of cells of C. albicans. Exponentially growing cells of $C$. albicans were grown in YNB containing different concentrations of ethanol. Samples were removed at the times indicated, diluted and plated on GPA. Ethanol concentrations $(v / v)$ were $5 \%(O), 7 \%(0), 9 \%(\Delta)$, $11 \%(\triangle)$ or $13 \%(\square)$

Table 1. Retardation of growth of C. albicans strains 300,304 and 336 in $Y N B$ at $37^{\circ} \mathrm{C}$ with different concentrations of ethanol

About $5 \times 10^{6}$ cells $\mathrm{ml}^{-1}$ were inoculated into YNB with $1 \%(\mathrm{w} / \mathrm{v})$ glucose initially. Growth was monitored by measurements in a Klett-Summerson photoelectric colorimeter. There was no growth by any of the strains in $5 \%(\mathrm{v} / \mathrm{v})$ ethanol. The results of a representative experiment are recorded. The observations on strain 300 were repeated six times, while those on strain 304 and strain 336 were repeated once with comparable results.

$\begin{array}{lllll}\begin{array}{l}\text { Ethanol } \\ \text { concn }(\%, v / v)\end{array} & \ldots & \overbrace{0} & 1 & 2 \\ \operatorname{lag}(\mathrm{h}) & 2 & 2 & 4 \\ \text { time }(\mathrm{h}) & & 1.8 & 2.6 & 2.7\end{array}$

$\overbrace{0} \begin{array}{lll}1 & 2 \\ 2 & 3 & 4 \\ 1.8 & 2 \cdot 6 & 2 \cdot 7\end{array}$

$\overbrace{0} \begin{array}{lll}1 & 2 \\ 2 & 4 & 4 \\ 1.9 & 3.0 & 4.4\end{array}$

Length of lag $(\mathrm{h})$
Generation time $(\mathrm{h})$ in exponential phase 


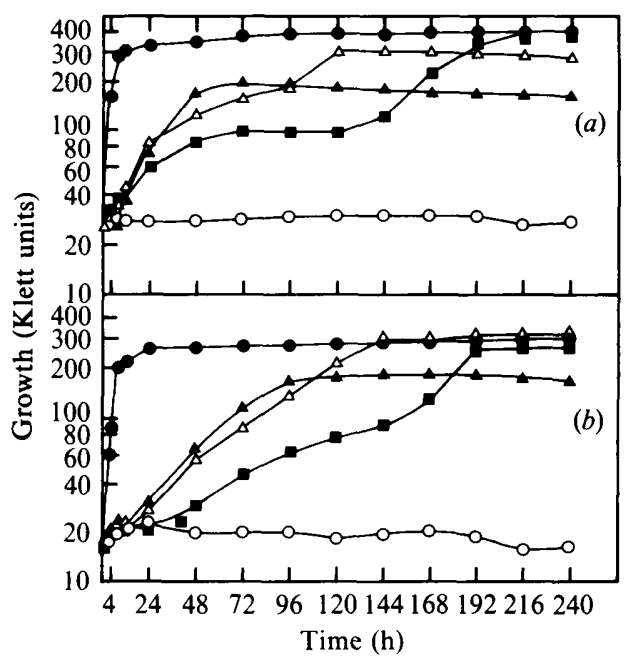

Fig. 3. Growth of $C$. albicans strain $300(a)$ and strain $336(b)$ on ethanol as sole source of carbon. About $5 \times 10^{6}$ cells $\mathrm{ml}^{-1}$ were inoculated into YNB with different concentrations $(\mathrm{v} / \mathrm{v})$ of ethanol $\triangle, 0.25 \%$; $\Delta, 0.50 \% ; \nabla, 1 \%$ or with $1 \%(w / v)$ glucose $(\bigcirc)$ as a control. $\bigcirc$, No carbon source. Growth was measured in a Klett-Summerson photoelectric colorimeter.

Table 2. Maximum ethanol production by C. albicans strain 300 grown at different glucose concentrations

$\begin{array}{ccccc}\begin{array}{c}\text { Glucose } \\ \text { concn } \\ (\%, \mathrm{w} / \mathrm{v})\end{array} & \begin{array}{c}\text { Maximum } \\ \text { ethanol } \\ \text { production } \\ (\%, \mathrm{w} / \mathrm{v})\end{array} & \begin{array}{c}\text { Time } \\ \text { required } \\ (\mathrm{h})\end{array} & \begin{array}{c}\text { Residual } \\ \text { glucose } \\ \text { concn } \\ (\%), \mathrm{w} / \mathrm{v})\end{array} & \begin{array}{c}\text { Percentage of } \\ \text { theoretical } \\ \text { yield* }\end{array} \\ 1 & 0.3 & 17 & 0 & 60 \\ 2 & 0.8 & 17 & 0 & 72 \\ 5 & 1.9 & 40 & 0 & 70 \\ 7 & 3.1 & 48 & 0 & 80 \\ 10 & 3.7 & 160 & 1 \cdot 7 & 74 \\ 15 & 4.3 & 240 & 4.1 & 60\end{array}$

* These calculations were based on the assumption that one molecule of glucose is converted to two molecules each of ethanol and $\mathrm{CO}_{2}$. On a weight basis, $51 \cdot 1 \%$ of the glucose is converted to ethanol and $48.9 \%$ to $\mathrm{CO}_{2}$ (Kunkee \& Amerine, 1970). The data represent results from a representative experiment that was repeated once with comparable results.

twice as much ethanol in the same time and did not utilize the substance during the remaining incubation period. In $5 \%$ glucose about five times as much ethanol was produced as had been from $1 \%$ glucose but a longer period of time was required (Table 2) which may reflect the toxicity of the end-product for the cells. In a similar way larger amounts of ethanol were produced over longer periods of time from starting concentrations of glucose of 7,10 and $15 \%$ (Table 2). Substantial amounts of ethanol can be produced from relatively large concentrations of glucose in the medium. The yields were $60-80 \%$ of those expected (Table 2). Similar results were obtained from a repeat of the entire experiment depicted in Table 2 and from a study of strain 336 under the same experimental circumstances (data not shown). Final concentrations of $0.3-3.0 \%$ ethanol did not reduce the viability of the cells but concentrations of $4 \%$ or greater sterilized the cultures even though fermentation continued for a time after cell death (data not shown). Thus the fermentation rate was less sensitive to ethanol than was the growth rate (D'Amore \& Stewart, 1987). 


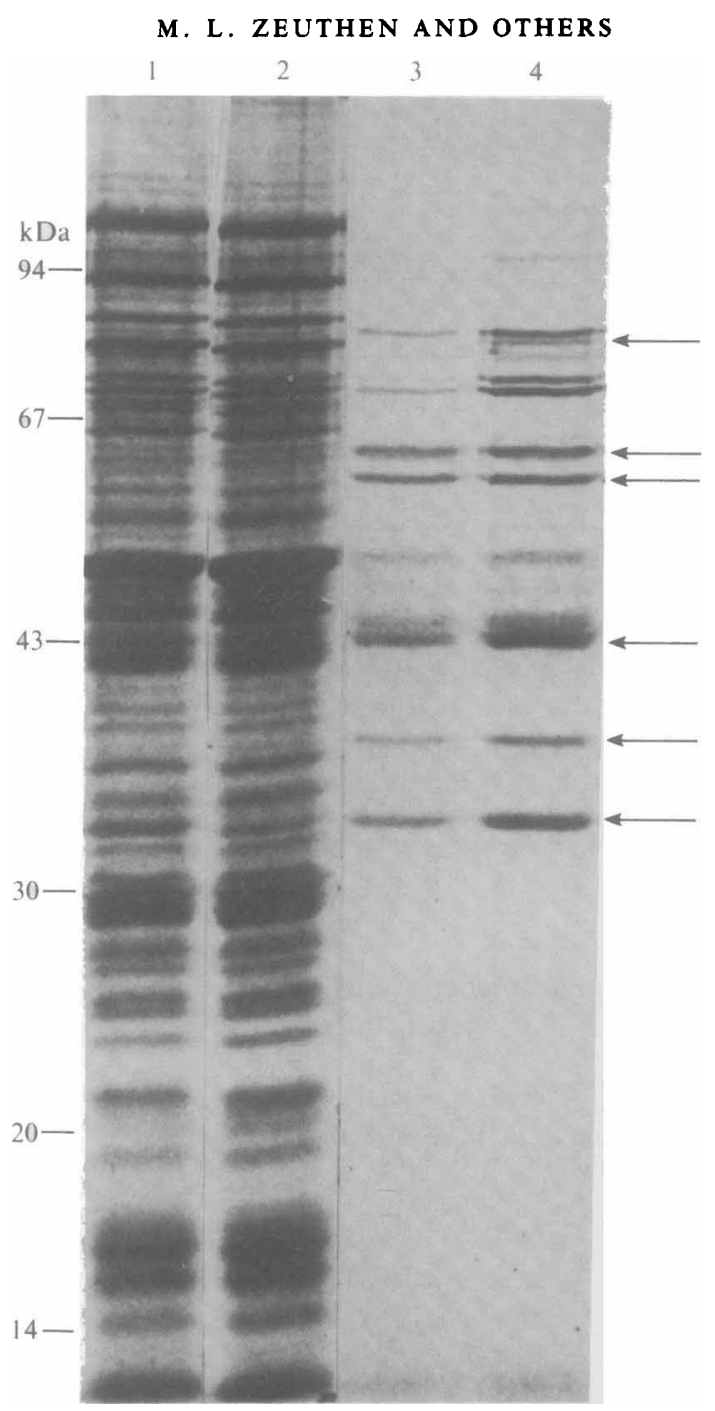

Fig. 4. Autoradiogram of cellular proteins separated electrophoretically by SDS-PAGE $(12 \%, w / v$, polyacrylamide). Cells of C. albicans strain 300 were exposed to $7 \%$ (v/v) ethanol for 20 and $40 \mathrm{~min}$ at $23{ }^{\circ} \mathrm{C}$. Cells were pulse-labelled $\left(0-20 \mathrm{~min}-\right.$ lane $3 ; 20-40 \mathrm{~min}$ - lane 4) with L-[ $\left.{ }^{35} \mathrm{~S}\right]$ methionine $\left(0.26 \mathrm{MBq} \mathrm{ml} l^{-1}\right.$; specific activity $\left.5.5 \mathrm{TBq} \mathrm{mmol}^{-1}\right)$ during exposure to ethanol. Cellular proteins from cells not exposed to ethanol and pulse-labelled (0-20 $\mathrm{min}-$ lane 1; 20-40 $\mathrm{min}-$ lane 2$)$ are included in the Figure as controls. The values on the left represent molecular mass standards in $\mathrm{kDa}$. The arrows point to the ESPs.

Table 3. Ethanol induction of germ tubes in different strains of C. albicans

Values are means of three separate determinations.

\begin{tabular}{|c|c|c|c|c|c|c|c|c|}
\hline \multirow[b]{2}{*}{ Strain } & \multirow[b]{2}{*}{$\begin{array}{c}\text { LBC } \\
\text { medium* }\end{array}$} & \multicolumn{7}{|c|}{$\begin{array}{l}\text { Percentage of cells forming germ tubes at } \\
\text { an ethanol concentration }(\%, v / v) \text { of : }\end{array}$} \\
\hline & & $4 \cdot 0$ & $2 \cdot 0$ & $1 \cdot 0$ & 0.50 & 0.25 & 0.06 & 0.015 \\
\hline 300 & 87 & 0 & 11 & 48 & 59 & 60 & 39 & 26 \\
\hline 304 & 91 & 0 & 67 & 69 & 65 & 58 & 21 & 20 \\
\hline 320 & 85 & 0 & 16 & 69 & 48 & 26 & 40 & 3 \\
\hline 336 & 82 & 0 & 90 & 79 & 69 & 63 & 22 & 10 \\
\hline
\end{tabular}

${ }^{*}$ Mean percentage germ tube formation (three separate determinations) in LBC synthetic medium (Lee et al., 1975. The entire experiment was repeated once: the values varied slightly but were comparable. 


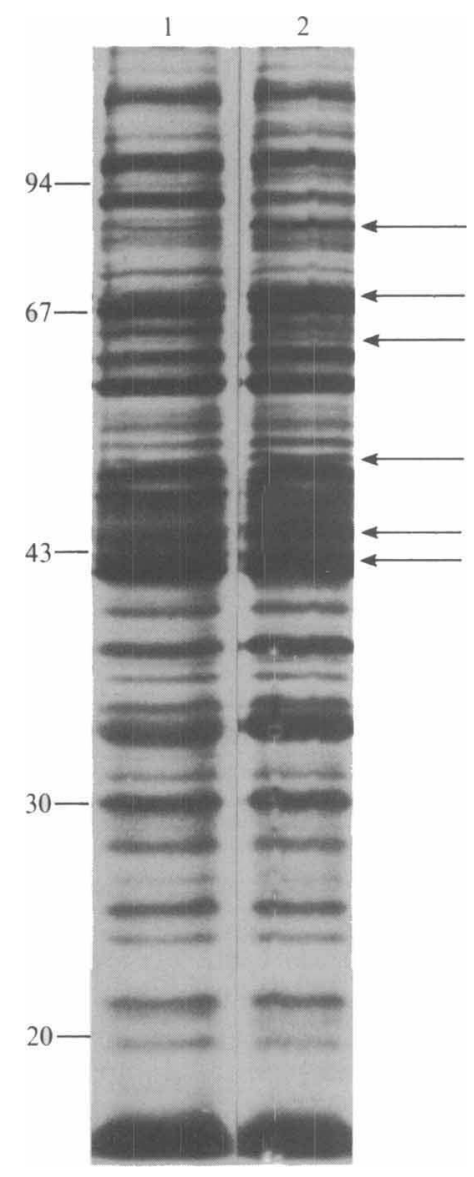

Fig. 5. Autoradiogram of cellular proteins separated in the same manner as those shown in Fig. 4. Yeast cells were shifted from 23 to $37^{\circ} \mathrm{C}$. Cells were pulse-labelled during the period 20-40 min after shift-up (lane 2) with $L-\left[{ }^{35} S\right]$ methionine (0.26 MBq ml-1 ; specific activity $5.5 \mathrm{TBq} \mathrm{mmol}^{-1}$. Control cells kept at $23^{\circ} \mathrm{C}$ were similarly pulse-labelled (lane 1 ). The values on the left represent molecular mass standards in $\mathrm{kDa}$. (Note that the scale is slightly different from that of Fig. 4.) The arrows point to the HSPs.

\section{Ethanol induction of germ tube formation}

Four strains of $C$. albicans $(300,304,320$ and 336) were used to determine what concentrations of ethanol would induce germ tube formation. Cells grown on GPA at $25^{\circ} \mathrm{C}$ were suspended in phosphate buffer containing different concentrations of ethanol. Germ tube formation was assessed after $3 \mathrm{~h}$ incubation at $37^{\circ} \mathrm{C}$. The results are shown in Table 3. Germ tubes were formed by all four strains at concentrations of ethanol $(0.015-2 \%)$ that could be generated metabolically by the fungus. The maximum germination was obtained at concentrations of $0 \cdot 25-1 \%$. No germination occurred at $4.0 \%$ ethanol or below $0.015 \%$. There was some variation in the percentage of cells forming germ tubes among the four strains, a feature seen with other inducers (Dabrowa et al., 1976). Although the concentrations of ethanol produced metabolically from $1-2 \%(w / v)$ glucose are those that promoted germination in the studies reported in Table 3, germ tube formation was not seen in the fermentation experiments reported in Table 2.

\section{Ethanol stress proteins}

The effect of ethanol on the synthesis of proteins by strain 300 of $C$. albicans was studied. Extracts were prepared from cells radiolabelled in $\left[{ }^{35}\right.$ S]methionine, and the proteins within the extracts were separated by single-dimensional SDS-PAGE. The labelled proteins were revealed by autoradiography of slab gels.

The results from a typical experiment are shown in Fig. 4. Exposure of the cells to $7 \%$ ethanol at $23{ }^{\circ} \mathrm{C}$ strongly suppressed normal protein synthesis. Analysis of the gels revealed six proteins that were synthesized either uniquely or at markedly enhanced levels. Their apparent molecular masses were $34,38,46,64,68$ and $82 \mathrm{kDa}$. 
Although normal protein synthesis was depressed, there were a few proteins whose synthesis was impaired but partially ( 79 and $95 \mathrm{kDa}$ ) or almost completely $(49,55,74,75$ and $84 \mathrm{kDa})$ recovered over the $40 \mathrm{~min}$ period of observation.

The same results were achieved when $5 \%$ ethanol was used instead of $7 \%$. However, $10 \%$ ethanol shut-off all protein synthesis. Cells of strain 303 grown at $37^{\circ} \mathrm{C}$ and incubated at that temperature in 5 and $7 \%$ ethanol formed the same stress proteins as those incubated at $23{ }^{\circ} \mathrm{C}$ (data not shown).

In the experiments on ESPs temperature shift was not a part of the protocol. In order to compare ESPs with HSPs an experiment was done in which yeast cells were grown at $23^{\circ} \mathrm{C}$ and shifted to $37^{\circ} \mathrm{C}$. The proteins synthesized 20-40 min after the shift are shown in Fig. 5. Six HSPs were observed. Their apparent molecular masses were 43, 48, 56, 64, 73 and $84 \mathrm{kDa}$. Four of these were similar in molecular mass $(48,64,73$ and $84 \mathrm{kDa})$ to the ESPs (Fig. 4).

\section{DISCUSSION}

Tolerance of ethanol among micro-organisms has been measured in a variety of ways (Casey \& Ingledew, 1986; Juroszek et al., 1987). We assessed the inhibition of growth by ethanol in broth culture and the effects of ethanol on cell viability: $5 \%$ ethanol completely suppressed the growth of the C. albicans strain 300 . This level of tolerance is well below that recorded for most alcohol-producing species of Saccharomyces (Casey \& Ingledew, 1986) and would categorize strain 300 as poorly tolerant by the criteria of one group of workers (Casey $\&$ Ingledew, 1986). We observed that $11 \%$ ethanol reduced the viability of strain 300 by $90 \%$ in $3 \mathrm{~h}$. This same reduction in viability of a strain of $S$. cerevisiae required nearly twice the concentration $(21 \%)$ of ethanol (Casey \& Ingledew, 1986). Therefore, strain 300 C. albicans was relatively intolerant of ethanol in comparison to $S$. cerevisiae. The basis of ethanol resistance is unknown (Juroszek $e t$ $a l ., 1987)$ and the role of the stress proteins in that resistance needs more study (Plesset et al., 1982). The other strains used in our study (304 and 336) were also sensitive to levels of ethanol that do not adversely affect other well-studied yeasts (Casey \& Ingledew, 1986).

The catabolism of glucose by C. albicans to produce ethanol has been reported (Pappagianis \& Marovitz, 1966; Wilson et al., 1966). In studies on the use of an alcohol test for cryptococcal meningitis Wilson et al. (1966) studied the in vitro production of ethanol by strains of Cryptococcus neoformans and compared it with alcohol formation by $C$. albicans. They reported that five strains of $C$. albicans produced from $260-339 \mu \mathrm{mol}$ ethanol per $\mathrm{ml}$ of medium after $48 \mathrm{~h}$ at $34{ }^{\circ} \mathrm{C}$ in stagnant cultures. The maximum yield of ethanol was about $15 \%$ of the theoretical yield. Pappagianis \& Marovitz (1966) also reported ethanol production by $C$. neoformans and $C$. albicans. These investigators recorded a maximum ethanol production (determined enzymically) of $62 \%$ of a theoretical yield. The data shown in Table 2 of our report indicate that the yields achieved were from $60-80 \%$ of theoretical values.

Concentrations of ethanol ranging from $0 \cdot 25-1 \cdot 0 \%(\mathrm{v} / \mathrm{v})$, i.e. $0 \cdot 21-0 \cdot 8 \%(\mathrm{w} / \mathrm{v})$, are those in the range generated from 1 and $2 \%(\mathrm{w} / \mathrm{v})$ glucose in $24 \mathrm{~h}$ (Table 2). Thus $C$. albicans could generate amounts of ethanol that stimulate germ tube formation from the concentrations of glucose $(1-2 \%, w / v)$ in culture media commonly used to grow the fungus. But blastoconidial germination was not seen in the batch cultures and spent medium with freshly grown cells did not promote germination of these cells (data not shown). From our observation it would appear unlikely that ethanol is a morphogen in $C$. albicans under most conditions of cultivation.

Stress proteins may be involved in the regulation of morphogenetic events in zoopathogenic fungi. Differentiation specific proteins of 34.7 and $21.9 \mathrm{kDa}$ were induced in uredospore germlings of the wheat stem rust, Puccinia graminis tritici, after heat shock (Wanner et al., 1985). Thus heat shock induced differentiation of germlings in the absence of the customary contact stimuli. In another study, nutritional stress induced the synthesis of 28 proteins (nutritional stress proteins, NSP) in Achlya klebsiana and some of these proteins appeared to be involved in development of asexual sporangia and sporulation by the fungus (LeJohn \& Braithwaite, 1984).

Ethanol induces a number of morphologic changes in fungi including germ tube formation by C. albicans (see Pollack \& Hashimoto, 1985; Reynouard et al., 1979). Since ethanol induces stress 
proteins in $C$. albicans, it would be of interest to derive further information on the potential regulatory role of such proteins.

In response to ethanol C. albicans displays an altered pattern of protein synthesis. Six proteins of $34,38,46,64,68$ and $82 \mathrm{kDa}$ were predominately synthesized during short-term exposure to $7 \%$ ethanol. Four of these are similar in size to the HSPs $(46,64,68$ and $82 \mathrm{kDa})$ synthesized by cells shifted from 23 to $37{ }^{\circ} \mathrm{C}$. Two of the ESPs ( 68 and $82 \mathrm{kDa}$ ) are like the highly conserved HSPs seen in many cells (Ashburner \& Bonner, 1979; Dabrowa \& Howard, 1984; Ingolia et al., 1982; Kelly \& Schlessinger, 1982; Welch \& Feramisco, 1984) and two others (34 and $38 \mathrm{kDa}$ ) are similar to a minor and a major HSP of Neurospora crassa (Plesofsky-Vig \& Brambl, 1985). The need for a thorough study of stress-induced proteins and their morphogenetic influence in C. albicans is indicated by our preliminary work.

This investigation was supported by Public Health Service grant AI-16252 from the National Institute of Allergy and Infectious Diseases, NIH, Bethesda, Md. We are grateful to Ms Eufemia Tsui for skilful technical assistance and we thank Ms Lois Howard for her care in preparing the manuscript. We thank Dr Frank Bayliss, California State University, San Francisco; Dr Cal McLaughlin, University of California, Irvine; and Dr Rishab Gupta, University of California, Los Angeles, for reading and criticizing the manuscript. This is publication no. 131 of the Collaborative California Universities Mycology Research Unit (CCU-MRU).

\section{REFERENCES}

Ashburner, M. \& Bonner, J. J. (1979). The induction of gene activity in Drosophila by heat shock. Cell 17, 241-254.

CASEY, G. P. \& INGledew, W. M. (1986). Ethanol tolerance in yeasts. CRC Critical Reviews in Microbiology 13, 219-280.

Dabrowa, N. \& Howard, D. H. (1984). Heat shock and heat stroke proteins observed during germination of the blastoconidia of Candida albicans. Infection and Immunity 44, 537-539.

Dabrowa, N., TAXer, S. S. S. \& Howard, D. H. (1976). Germination of Candida albicans induced by proline. Infection and Immunity 13, 830-835.

Dabrowa, N., ZeUTHEN, M. L. \& Howard, D. H. (1986). Abstracts of the Annual Meeting of the American Society for Microbiology F48, 405.

D'Amore, T. \& Stewart, G. G. (1987). Ethanol tolerance of yeast. Enzyme and Microbial Technology 9, 322-330.

Gibbons, G. F. \& Howard, D. H. (1986). Arginine auxotrophs of Candida albicans deficient in arginosuccinate lyase. Journal of General Microbiology 32, 263-268.

Howard, D. H., Zeuthen, M. L. \& Dabrowa, N. (1986). Phenotypic characteristics of a slow-growing, nongerminating variant of Candida albicans. Journal of General Microbiology 132, 2359-2366.

INGolia, T. D., Slater, M. R. \& Craig, E. A. (1982). Saccharomyces cerevisiae contains a complex multigene family related to the major heat-inducible gene of Drosophila. Molecular and Cellular Biology 2, 1388-1398.

IWATA, K. (1976). A review of the literature on drunken symptoms due to yeast in gastrointestinal tract. Yeasts and Yeast-like Microorganisms in Medical Science: Proceedings of the Second International Specialized Symposium on Yeasts (1972), pp. 260-268. Edited by K. Iwata. Tokyo: University of Tokyo Press.

Juroszek, J.-R., Feulllat, M. \& Charpentier, C. (1987). Effect of ethanol on the glucose-induced movements of protons across the plasma membrane of Saccharomyces cerevisiae NCYC 431. Canadian Journal of Microbiology 33, 93-97.

Kelly, P. M. \& SChlessinger, M. J. (1982). Antibodies to two major heat-shock proteins cross-react with similar proteins in widely divergent species. Molecular and Cellular Biology 2, 267-274.

KunKeE, R. E. \& AMERINe, M. A. (1970). Yeasts in wine making. In The Yeasts, vol. 3, pp. 5-71. Edited by A. H. Rose \& J. S. Harrison. New York: Academic Press.

Lee, K. L., Buckley, H. R. \& Campbell, C. C. (1975). An amino acid liquid synthetic medium for the development of mycelial and yeast forms of Candida albicans. Sabouraudia 13, 148-153.

LeJohn, H. B. \& Braithwaite, C. E. (1984). Heat and nutritional shock-induced proteins of the fungus Achlya are different and under independent transcriptional control. Canadian Journal of Biochemistry and Cell Biology 62, 837-846.

MCGINNIS, M. R. (1980). Laboratory Handbook of Medical Mycology, pp. 364-366. New York: Academic Press.

MORRISSEY, J. H. (1981). Silver stain for proteins in polyacrylamide gels: a modified procedure with enhanced uniform sensitivity. Analytical Biochemis try 117, 307-310.

ODDS, C. (1979). Candida and Candidosis. Baltimore: University Park Press.

Pappagianis, D. \& Marovitz, R. (1966). Studies on ethanol production by Cryptococcus neoformans. Sabouraudia 4, 250-255.

Plesofsky-Vig, N. \& BRambl, R. (1985). Heat shock response in Neurospora crassa: protein synthesis and induced thermotolerance. Journal of Bacteriology 162, 1083-1091.

Plesset, J., Palm, C. \& Mclaughlin, C. S. (1982). Induction of heat shock proteins and tolerance by ethanol in Saccharomyces cerevisiae. Biochemical and Biophysical Research Communications 108, 1340 1345. 
Pollack, J. H. \& Hashimoto, T. (1985). Ethanolinduced germ tube formation in Candida albicans. Journal of General Microbiology 131, 3303-3310.

REYNOUARD, F., LACROIX, J., LACROIX, R. \& COMBESCOT, C. (1979). Influence de certains alcools sur la filamentation du Candida albicans en culture. Annales pharmaceutiques françaises 37, 213-216.

ShePherd, M. G., Poulter, R. T. M. \& Sullivan, P. A. (1985). Candida albicans: biology, genetics and pathogenicity. Annual Review of Microbiology 39, 579-614.

Wanner, R., Forster, H., Mendgen, K. \& Staples, R. C. (1985). Synthesis of differentiation-specific proteins in germlings of the wheat stem rust fungus after heat shock. Experimental Mycology 9, 279-283.

Welch, W. J. \& Feramisco, J. R. (1984). Nuclear and nucleolar localization of the 72000-dalton heat shock protein in heat-shocked mammalian cells. Journal of Biological Chemistry 259, 4501-4513.

Wilson, D. E., Williams, T. W., JR \& BennetT, J. E. (1966). Further experiments with the alcohol test for cryptococcal meningitis. American Journal of the Medical Sciences 252, 532-536.

ZEUTHEN, M. L. \& HowARD, D. H. (1986). Abstracts of the Annual Meeting of the American Society for Microbiology F59, 407. 